\title{
Teacher Perceptions about the Potential of Blogs as an Information Source
}

\author{
Abdus Sattar Chaudhry, Hdeel Al-Shammari \\ College of Social Sciences, Kuwait University \\ Kuwait
}

\begin{abstract}
Interviews with English language teachers indicated that usage of blogs in Kuwaiti schools was low and infrequent. However, teacher feedback indicated that they perceived that Blogs have good potential as an information source and a tool to support learning and teaching. Teachers reported the lack of time, limited computing skills and English langue ability of students and teachers were the main barriers impeding the use of blogs. Teachers considered training in building and using blogs important for effective use of blogs as a teaching tool. They would like to use blogs for posting teaching materials, commenting on the postings, and discussions.
\end{abstract}

\section{Introduction}

Blogs, written by either single or several authors are an ideal tool for disseminating regular commentary and opinion. Multi-author blogs in particular can provide an opportunity for improving professional communication. Students can use blogs to support \& develop their learning. These blogs are often reflective and might be private, shared with a teacher or completely public. Blogs appear to have good potential as an information source in education. Blogs are easy to build ad use. Educational blogs are particularly useful for the following: share materials and links; facilitate online discussion and collaboration; create a class publication; get students to do blogging to share their ideas; get feedback; and create a fully functional website. While blogs are quite common in Kuwait, we could not find any study done on use of blogs in Kuwaiti schools.

We carried out a study to investigate if teachers in Kuwait were able to take advantage of the potential of blogs as an educational tool. We sought teachers' views on the potential of blogs for supporting teaching and learning activities in Kuwaiti schools. The study focused on the following questions:

- Are teachers in Kuwaiti schools currently using blogs?

- What factors are affecting the use of blogs in Kuwaiti schools?

- What are the teacher perceptions about the use of blogs in schools?
- How prepared are the teachers to use blogs to support teaching?

\section{Background}

Kuwait is located in southwestern Asia on the northwestern coast of the Arabian Gulf, bounded on the north by Iraq, on the east by the Arabian Gulf, and on the south by Saudi Arabia. The country's total area is 6,880 square miles and population is approximately 3.5 million. Kuwait's economy depends mainly on crude oil, petrochemical industries, overseas investments, and banking and financial services. Arabic is the official language of the country but English is widely understood and used. Kuwait supports an educational policy that seeks to provide opportunity to all children, irrespective of their social class. Kuwait was ranked 63rd on the Human Development Human Index (HDI) report for 2011 by UNDP. In 2005, the literacy rate of Kuwait was 94 percent [1].

The general education system consists of four levels: kindergarten (lasting for 2 years), primary (lasting for 5 years), intermediate (lasting for 4 years) and secondary (lasting for 3 years). Schooling at primary and intermediate level is compulsory for all students aged 6-14. All the levels of state education are free. There are two main ministries involved in the development of the education sector: the Ministry of Education and the Ministry of Higher of Education. There are more than 1100 schools in Kuwait, at all levels from kindergarten to secondary. Out of this total, more than 600 are public schools. About two-thirds of all students are in public schools. Most Kuwaitis study in public schools. A large proportion of public school teachers are Kuwaiti females, particularly at the primary level [2].

\section{Literature Review}

Williams and Jacobs emphasized on the pedagogical reasoning for the use of blogging in education highlighting the capacity of blogs to engage people in collaborative activities [3]. Zinger \& Sinclair stated that blogs have the potential to enhance student engagement and learning. Blogs can facilitate the learning process and strengthen the 
relationship between teachers and students [4]. Blogs also help communicate with students to support the various learning activities. Teachers can use blogs to improve teaching and motivate students to write and read. Wan reported numerous benefits of using weblogs in English language learning by using weblogs. He stated that weblogs are promising as interactive tools for English language learning [5].

Philpott stated that with all the various information sources available online today many favor blogs as their primary source of information online [6]. This is due primarily to the fact that blogs are unencumbered concerning the accuracy of what their content contains. A blog platform typically circumvents the traditional red tape that can slow the delivery of news from syndicated sites. He cautioned that without any type of regulation in place blog posting sometimes tends to reflect more of the writers opinions.

Sheagley pointed out two important aspects of blogs that required study: their perceived source credibility and the potential impact of their highly partisan nature. Given their apparent dissimilarity to other mediums of communication, due to their usercreated content and high levels of partisanship, careful analysis is necessary before predicting how blogs might have an impact people. He highlights on information processing, specifically recent work on motivation and framing effects to create a theory of the psychological mechanisms at work when/if people search for and read political blogs [7].

Lutcher examined teachers' perceptions about the impact of the programs for the acquisition of the 21st Century skills associated with the use of blogs and wikis by students and teachers. Results from this study indicate teachers believe student use of blogs increased their skills. Collaboration, communication, basic literacy, digital literacy, and global awareness skills all increased after using a blog or a wiki. Results also indicated a change in teacher practice from a teacher led classroom to a student centered classroom environment. Teachers perceived that as students acquired 21st Century Skills and teachers changed their classroom practice, students became empowered to take control of their learning [8].

Aydan investigated the benefits and challenges of using blogs in English as a Foreign Language. The findings of the study indicated that blogs provided many advantages to the students, especially for improving various skills such as reading and writing and vocabulary and grammar knowledge. They also motivated students to attend reading classes more actively and to do more research on the topic [9].

\section{Methodology}

The survey method was used to carry out the study on use of blogs. We selected three schools for the study. These schools were selected considering the accessibility of teachers and practical considerations for logistics of data collection. Our study was restricted to English teachers, as only English teachers had the materials, which would be appropriate for posting on blogs. At the time of the study, there were in total 41 teachers who were teaching English in the selected three schools. All teachers agreed to participate. All of them are female. They hold a Bachelor degree in Education or English Language from Kuwait University or the Public Authority for Applied Education and Training (PAFET) in Kuwait.

The structured interviews have been used to collect data. We prepared a questionnaire as an interview schedule. We interviewed the teachers as a group in each school. We sent copies of interview schedule to all participating teachers in advance and informed about the date, time and place of interview one week before the interviews. We provided brief introduction summarizing the main features of blogs to support learning and teaching activities before the conduct of interviews. In addition to answering the interview questions, the teachers discussed the possible uses of blogs and put forward various suggestions to activate the use of blogs in their classrooms. We conducted all interviews in two weeks (week $8 \& 9$ ) during the first semester of the school year (academic year 2013-14).

We asked the participants if they would be willing to participate in follow-up focus group discussions. Seven teachers agreed. We conducted a series of focus group discussions with these teachers. These discussions aimed at discussing the suggestions put forward in the interviews and the issues raised by participants on the study. A guide was prepared to conduct the discussions. Interview guide consisted of questions regarding policy implications and cultural considerations for blogs, nature of training that would be helpful for preparing teachers to take advantage of the potential of blogs, and guidelines for developing and posting contents on blogs, and managing collaboration and communication on blogs. The discussions helped build consensus on issues that helped put the results of the study in to a proper context. The discussions also helped to put suggestions for taking appropriate steps to encourage and promote the use of blogs in Kuwait schools.

\section{Findings}

Majority of teachers who participated in the study was between the age ranges of 25-35. Most of them have more than 5 years of teaching experience. Majority of teacher (21) were teaching English to elementary (1-5) classes, 14 were teaching at secondary level (10-12), and six to middle classes (6$9)$. All teachers hold graduate degrees in English or Education. 


\subsection{Current Usage of Blogs}

Only $25.7 \%$ teachers reported that they were using blogs at the time of the study. They were using blogs for the following purposes: Informing and instructing, communication with students, posting materials, writing, and quizzes. Majority of the teachers $(74.3 \%)$ were not using blogs. Frequency of usage varied: $22.2 \%$ were using blogs more than three times a week while $33.3 \%$ were using blogs once or twice a week. However, the majority (44.4\%) were using blogs only once or twice a month. We asked the teachers asked about what were the factors that prohibited them to make use of blogs. Table 1 shows their responses.

Table 1: Barriers in Using Blogs

\begin{tabular}{|l|c|c|}
\hline \multicolumn{1}{|c|}{ Barriers } & $\begin{array}{c}\text { No. of } \\
\text { responses }\end{array}$ & $\%$ \\
\hline $\begin{array}{l}\text { Limited computer skills of } \\
\text { teachers }\end{array}$ & 23 & $56.7 \%$ \\
\hline Limited English ability & 6 & $3.3 \%$ \\
\hline $\begin{array}{l}\text { Lack interest among } \\
\text { teachers }\end{array}$ & 14 & $46.7 \%$ \\
\hline Lack of time for blogging & 24 & $80.0 \%$ \\
\hline $\begin{array}{l}\text { Limited English ability of } \\
\text { students }\end{array}$ & 4 & $13.3 \%$ \\
\hline $\begin{array}{l}\text { Limited computer } \\
\text { facilities in schools }\end{array}$ & 3 & $10.0 \%$ \\
\hline $\begin{array}{l}\text { Limited computing skills } \\
\text { of students }\end{array}$ & 2 & $6.7 \%$ \\
\hline $\begin{array}{l}\text { Lack of enthusiasm in } \\
\text { students to use blogs }\end{array}$ & 2 & $6.7 \%$ \\
\hline
\end{tabular}

Majority of the teachers interviewed reported that lack of time and lack of interest were the main barriers hindering the use of blogs. We asked the teachers if they would like to put forward any suggestions to encourage and promote the use of blogs in Kuwaiti schools. Participants suggested that students and teachers have computers in the classroom to encourage use of blogs. They also thought that training in building and using blogs would be helpful to leverage blogs as educational and teaching tools.

We asked the teachers that if the school administration and the Ministry of Education removed the barriers, what activities they would like to perform for using blogs to improve learning and teaching in schools. Table 2 shows their responses.

The three main activities perceived important by teachers for taking advantage of the potential of blogs were postings of supplemental materials, commenting on posts, and discussions on the postings by students and teachers. Hong reported that blogging allows students to reflect on what they are writing and thinking as they write and think [12]. They get engage readers and audience in a sustained conversation that leads to further thinking and writing. Students are able to synthesize disparate learning experiences and understand their collective relationship and relevance.

Table 2: Suggested Activities for Blogging

\begin{tabular}{|l|c|c|}
\hline \multicolumn{1}{|c|}{ Activity } & Frequency & Percent \\
\hline Writing & 19 & 0.6 \\
\hline Commenting & 28 & 15.2 \\
\hline Student feedback & 24 & 12.2 \\
\hline $\begin{array}{l}\text { Informing and } \\
\text { instructing }\end{array}$ & 30 & 2.4 \\
\hline $\begin{array}{l}\text { Posting supplementing } \\
\text { material }\end{array}$ & 31 & 15.7 \\
\hline Quizzes & 18 & 9.1 \\
\hline Discussion & 26 & 13.2 \\
\hline $\begin{array}{l}\text { Blogging as } \\
\text { assignment }\end{array}$ & 21 & 17.7 \\
\hline
\end{tabular}

Yang explored the use of blogs as a reflective platform in the training processes of English as a foreign language [10]. His study surveyed the teachers who were training the student for future employment in Taiwan [11]. They were using blogs to reflect their learning process and to gauge the impact of blogs on their own professional growth. They also use it as a discussion form so that the student and teachers could engage in and examine their own reflection process. The results of this study showed that blogs are useful platform for reflecting, discussing, and communicating. Räisänen reported seven uses of blogs in teacher student communication. These include informing and instructing, posting supplemental material, prompting, blogging as assignment, community building, discussion/collaboration, and interacting with external readers/cementers [11]. He also found that schools use blogs to increase the transparency of examinations and to strengthen the student-teacher relationship through what he called social posts.

\subsection{Teacher Perceptions about the Potential of Blogs}

The focus of this study was to investigate the perspectives of teachers about the potential of using blogs, irrespective of their current level of usage. Ten statements about blogs were presented to them and they were asked to show their agreement to these statements on a scale of 1 to 5 (' 1 ' showing, disagree and ' 5 ', strongly agree). Table 3 lists their perceptions. 
Table 3: Teacher Perceptions about Potential of Blogs

\begin{tabular}{|l|c|c|}
\hline \multicolumn{1}{|c|}{ Statement } & Mean & $\begin{array}{c}\text { Standard } \\
\text { Deviation }\end{array}$ \\
\hline $\begin{array}{l}\text { Blog provides non-native } \\
\text { speakers of English with } \\
\text { a rich learning } \\
\text { environment. }\end{array}$ & 3.68 & .789 \\
\hline $\begin{array}{l}\text { Blog tools are helpful in } \\
\text { achieving teaching } \\
\text { purposes. }\end{array}$ & 3.71 & .680 \\
\hline $\begin{array}{l}\text { Blog resources can } \\
\text { replace textbooks. }\end{array}$ & 2.66 & 1.237 \\
\hline $\begin{array}{l}\text { Use of blogs motivate } \\
\text { students for engagement } \\
\text { in the classroom. }\end{array}$ & 3.80 & .715 \\
\hline $\begin{array}{l}\text { Students can improve } \\
\text { their English skills by } \\
\text { using blogs. }\end{array}$ & 3.78 & .790 \\
\hline $\begin{array}{l}\text { Students can learn how } \\
\text { to use blog resources for } \\
\text { learning English. }\end{array}$ & 3.98 &, 962 \\
\hline $\begin{array}{l}\text { Students will be more } \\
\text { attentive in blog-assisted } \\
\text { English language } \\
\text { teaching classes. }\end{array}$ & 3.95 & .705 \\
\hline $\begin{array}{l}\text { Students will be } \\
\text { motivated in } \\
\text { participating academic } \\
\text { work using blogs. }\end{array}$ & 3.80 & .954 \\
\hline $\begin{array}{l}\text { Students will be more } \\
\text { active in providing their } \\
\text { feedback. }\end{array}$ & 3.88 & .900 \\
\hline $\begin{array}{l}\text { Students will be } \\
\text { motivated in writing their } \\
\text { assignments in the blog. }\end{array}$ & 3.88 & \\
\hline
\end{tabular}

Teacher perspectives indicated (evidenced by the highest mean scores of 3.91, 3.86, and 3.80) that the benefits from use of blogs will improve English language of students, make them more attentive in classes, and get their feedback quickly on learning and teaching activities.

Kitchakarn pointed out that some of the difficulties that students experienced in writing can be overcome by using blog as a tool for writing [13] As a writing tool, blog can facilitate communication and interacting in several languages around the world.

Blogs provide a relaxed and safe environment for students especially those who feel shy. It provides them the opportunity to write and check their writing online without any obstacles. Using blogs make the writing process easier especially when blogs are user-friendly websites.

Al-Waely and Aburezeq studied pre-service Arabic language teachers' perceptions of using the blog as a learning tool. They identified the defects of collaborating via the blog and modified the use of blogs to facilitate effective learning [14]. Semistructured interviews with 14 pre-service teachers in addition to analyzing postings on the course blog were the used methods for collecting data. The results showed that the participants perceived the course blog as a powerful application to enhance their learning through facilitating active interaction with the instructor, peers and course content. However, the results also indicated a number of challenges and defects associated with the blog use for instructional purposes. Teachers provided good suggestions for effective use of blogs.

\subsection{Preparedness of Teachers}

The teachers were asked about their willingness to try blogs as educational tools. We also asked how comfortable they were in trying the blogs. They expressed their agreement on five statements on a scale of 1 to 5 (' 1 ' indicating disagree and ' 5 ', strongly agree) to indicate their readiness. Table 4 shows their responses.

Table 4: Readiness of Teachers to Use Blogs

\begin{tabular}{|l|c|c|}
\hline \multicolumn{1}{|c|}{ Statement } & Mean & $\begin{array}{c}\text { Standard } \\
\text { Deviation }\end{array}$ \\
\hline $\begin{array}{l}\text { I am responsible for the } \\
\text { success of blog for English } \\
\text { language teaching. }\end{array}$ & 3.71 & .929 \\
\hline $\begin{array}{l}\text { I am competent to use blog- } \\
\text { based materials in the } \\
\text { classroom. }\end{array}$ & 3.66 & .883 \\
\hline $\begin{array}{l}\text { I know how to integrate blog } \\
\text { resources into existing } \\
\text { classroom curricula. }\end{array}$ & 2.98 & 1.172 \\
\hline $\begin{array}{l}\text { I need training to improve my } \\
\text { skills in using blogs. }\end{array}$ & 4.20 & 1.005 \\
\hline $\begin{array}{l}\text { I would like to use blog-based } \\
\text { materials and activities in my } \\
\text { classroom as much as possible. }\end{array}$ & 4.27 & .742 \\
\hline
\end{tabular}

Most teachers (4.26 mean score) appear to be ready to use blogs in their classes. However, a majority of them (4.11 mean score) would like to get some sort of training in creating and using blogs. They also pointed out when asked to give suggestions to promote and encourage use of blogs in schools.

Using blogs is more than technology. Teachers should read other educators' blogs; how they use categories, how they organize the information, how often they blog, how they give instructions to students, etc. It requires learning new tool both technologically and methodologically. Teachers can post hyperlinks to websites that provide assignmentrelated homework help. Students can interact, 
develop their ideas, and express their opinion and receive feedback from their teachers. In addition, blogs are useful for posting class announcements and schedule reminders. It provides a fast, efficient means of communication, which encourage students and teachers to communicate, collaborate and interact in an easy way.

\section{Conclusion and Recommendations}

Blogs are considered easy to create, use, and simple to communicate. During the last few years, use of blogs has increased in different sectors including education. Various studies have highlighted that students and instructors are using blogs to post, comment, and participate and exchange ideas. Professional literature also pointed out that teachers could use blogs to communicate with their students and to get their feedback and provide explanations for students. Blogs have made the learning process easier and they provide opportunity for effective learning and knowledge sharing.

The results of this study showed that usage of blogs by teachers in Kuwaiti schools was low and infrequent. Lack of time and lack of interest were the main barriers in the use of blogs. Other impeding factors included limited computing skills and English langue ability of students and teachers. The participants suggested that availability of computers in the classroom would encourage teachers and students to use blogs. Teachers also pointed out that training in building \& using blogs would be helpful in effective use of blogs as a teaching tool. The participants pointed out that they would like to use blogs for the following three activities as their top preference: postings supplemental materials, commenting on the postings, and discussions by students.

Teacher perspectives indicated that the benefits from use of blogs would improve English language, make students more attentive in classes, and will assist in getting their feedback quickly on learning and teaching activities. Most teachers appear to be ready to use blogs in their classes. However, a majority of them would like to get some sort of training in creating and using blogs. This study has provided useful information on perspectives of teachers about the potential use of blogs as an educational tool. Further research is desirable to get further insights and in-depth understanding about the reasons for low usage of blogs and appropriate steps to encourage and promote the use of blogs in schools. More rigorous and qualitative methods of data collection, e.g., focus group discussions, will be more appropriate for future research on this topic. Teachers should read other educators' blogs; how they use categories, how they organize the information, how often they blog, how they give instructions to students, etc. It requires learning new tools both technologically and methodologically. In addition, if students are not used to using blogs, students could complete blogging tasks in class rather than after class. Students are able to participate in discussions to express their ideas and get access to the ideas of their classmates. Chai \& Kim pointed out that ideas are expressed by students with regard to a certain topic can be elaborated to encourage brainstorming. Chai \& Kim also found that blogging has positive effect on student reflectivity [15].

\section{References}

[1] State of Kuwait, Ministry of Education. (2009). National Report. Development of Education in Kuwait. KUWAIT, National Commission on Education, Science and Culture.

[2] Kuwait Education Indicators, 2007.

[3] Williams, J. B., and J. Jacobs. (2004). Exploring the use of blogs as learning spaces in the higher education sector. Australasian Journal of Educational Technology, 20 (2), 232-247. http://eprints.qut.edu.au/13066/1/13066.pdf

[4] Zinger, L., \& Sinclair, A. (2013). Using blogs to enhance student engagement and learning in the health sciences. Contemporary Issues in Education Research, 6(3), 349-352.

[5] Wan, J. (2011). Weblogs for English language learning: Students' perceptions. Turkish Online Journal of Distance Education, 12(4).

[6] Philpott, T.J. Are Blogs Reliable as Information Sources? http://www.selfgrowth.com/articles/ are_blogs_reliable_as_information_sources

[7] Sheagley, G., (2007). Blogs as information sources: The impact of source credibility and partisan affiliation. Midwest Political Science Association Conference.

http://internetadvocacycenter.com/thinktank/topics/ar ticles/Sheagley.pdf

[8] Lutcher, Robin L. (2011). Teachers' Perceptions on the Impact of Blogs and Wikis Regarding the Acquisition of 21st Century Skills in the Classrooms. A Study of Two Pennsylvania High Schools (doctoral dissertation, Indiana University of Pennsylvania).

[9] Aydan, Lütfiye Seda. (2014). Student and Teacher Perceptions on Benefits and Challenges of Using Blogs in English in Foreign Language Reading Classes (Master thesis, Middle Eastern Technical University). 
[10] Yang, S.-H. (2009). Using Blogs to Enhance Critical Reflection and Community of Practice. Educational Technology \& Society, 12 (2), 11-21.

[11] Räisänen, K. (2012). Using blogs for teacherstudent communication: Class blogs in two Swedish public schools (Doctoral dissertation, Örebro University).

[12] Hong, W. (2008). Exploring educational use of blogs in U.S. education. US-China Education Review, 5(10), 34-38.

[13] Kitchakarn, O. (2012). Using blogs to improve students' summary writing abilities. Turkish Online Journal of Distance Education, 13(4), 209-219.

[14] Al Waely,S. and Aburezeq, I. (2013). Using blogs to facilitate interactive and effective learning: Perceptions of pre-service Arabic teachers. Journal of Language Teaching and Research, 4(5), 975-985. doi:10.4304/jltr.4.5.975-985.

[15] Chai, S. \& Kim, M. (2010). What makes bloggers share knowledge? An investigation on the role of trust. International Journal of Information Management, 30(5), 408-415. 